\title{
The influence of entrepreneurial orientation on the performance of academic research groups: The mediating role of knowledge sharing
}

\author{
Esther Hormiga, University of Barcelona \\ Petra de Saá-Pérez, University of Las Palmas de Gran Canaria \\ Nieves L. Díaz-Díaz, University of Las Palmas de Gran Canaria \\ José Luis Ballesteros-Rodríguez, University of Las Palmas de Gran Canaria \\ Inmaculada Aguiar-Diaz, University of Las Palmas de Gran Canaria
}

\begin{abstract}
The objective of this research is to explore how entrepreneurial orientation (EO) contributes to explaining the performance of academic research groups through knowledge sharing. A questionnaire was used to collect data from 87 research groups (284 researchers) at a Spanish University. The relationships established were tested using 3SLS simultaneous equation models. We provide evidence in the present paper that the entrepreneurial orientation of research groups has a negative direct influence on performance, measured by the number of ISI articles published, if no knowledge sharing takes place between the group members. These results stress the importance of knowledge sharing in research groups in order to ensure that entrepreneurial group strategies (risky, proactive and innovative) are positive within an academic context.
\end{abstract}

Key words:

Entrepreneurial orientation, knowledge sharing, group research, performance

JEL: M150 


\section{Introduction}

In today's society, universities face different challenges just like any other kind of organization. The primary mission of a university is to create and transmit knowledge (Kao and Hung, 2008; Travaille and Hendriks, 2010) and it is important to understand how this type of organization is managed in order to stay competitive and to improve its research capacity (Rubiralta and Vendrell, 2002). Despite this, much less systematic attention is paid to the institutional mechanism of supporting knowledge production in old and new modes (Travaille and Hendriks, 2010).

Most research is performed in groups (Travaille and Hendriks, 2010), which provide the most natural way to organize research centres and research activity within universities. Nevertheless, while recognizing the strategic importance of research group activities at universities (e.g., Van Looy et al., 2006; Kao and Hung, 2008; Matsumoto et al., 2009), there are still few papers that focus on studying the link between the types of strategy and processes followed within research groups and their impact on the groups' performance (e.g., Harvey et al., 2002; Wang et al., 2006; Goodall, 2009).

In the literature on strategic management and entrepreneurship, many studies have demonstrated that a strategy-making process that provides organizations with a basis for entrepreneurial decisions and actions -an entrepreneurial orientation- can enhance performance (Van Door et al., 2013; Baker and Sinkula, 2009; Wiklund and Shepherd, 2003; Lumpkin and Dess, 1996). Indeed, entrepreneurial orientation reflects the priority that firms place on the process of identifying and exploiting new market opportunities (Shane and Venkataraman, 2000) and implies innovativeness, pro-activeness and risktaking (Covin and Slevin, 1989; Lumpkin and Dess, 1996; Wiklund and Shepherd, 2003; Lim and Envick, 2011). 
As far as a research group is concerned, instead of new market opportunities, researchers have to identify new research opportunities to provide society with new knowledge. In order to achieve optimum performance, it is important to provide pioneering and innovative orientation in the research group to identify new trends within the discipline and to be able to recognize new problems and new solutions for society (Harvey et al., 2002). The ability and motivation of university researchers to pursue entrepreneurial activities as a group will mostly involve a slow process of obtaining and consolidating strategic positions within the knowledge markets and innovation networks (Tijssen, 2006). Thus, the existence of entrepreneurial orientation in the group could play a key role in obtaining better output. However, we cannot find any empirical research in current literature that demonstrates this possible positive relationship between a group's EO and its performance, or, on the contrary, that shows if it is more positive for research groups to have a conservative strategy.

Moreover, it is important to note that researchers are knowledge workers, employed in the production of knowledge (Harvey et al., 2002). Scholars and practitioners have increasingly posited that effectiveness is dependent on how well knowledge is shared among individuals, groups and units (e.g., Spender and Grant, 1996; Alavi and Leidner, 2001; Tsai, 2001). If an effective knowledge sharing process is important for any organization or group, the very essence of research group activity makes it difficult to understand how any strategy or process can be successful without an effective means of sharing knowledge. If the proposals are new in the field, then sharing information with others and obtaining feedback, amplifications and modifications that add further value to the original sender, thus creating exponential total growth, will be very important (Cabrera and Cabrera, 2002). For this reason, it is vital to understand the role that 
knowledge sharing can play in the group, specifically when it has an entrepreneurial orientation.

Taking into account these considerations, the aim of this research is to contribute to the available literature by analysing the relationship between entrepreneurial orientation and research group performance, and identifying how knowledge sharing mediates this relationship.

In order to achieve the proposed objective, this paper is structured into five sections. Following this introduction, the paper analyses entrepreneurial orientation and knowledge sharing literature, in order to understand how these can impact on the performance of research groups. We formulate the corresponding hypothesis to explain how entrepreneurial orientation relates to research group performance, through effective knowledge sharing. The fourth and fifth sections are devoted to the method and to the analysis of the results, respectively. Empirical research was carried out by means of a survey of 291 academic researchers in 87 groups whose main objective is to produce new knowledge that advances scholarship in their academic specialties. Using three-stage least squares (3SLS), we make a contribution to the literature by finding a direct relationship between EO in research group performance and the mediating role of knowledge sharing. Finally, conclusions, limitations and future research lines are presented. 


\section{Entrepreneurial orientation and research group performance}

In general, universities are not the most entrepreneurial of institutions. One of the reasons for this is the hierarchical structure or the conservatism of the corporate culture (Kirby, 2006). Despite this, it appears that the idea of "entrepreneurial university" is a global phenomenon with an increasing number of supporters (Etzkowitz et al., 2000, Bercovitz and Feldmann, 2006). Thus, an entrepreneurial university has the ability to innovate, recognize and create opportunities, work in teams, take risks and respond to challenges (Kirby, 2002).

This study focuses on scientific research groups at universities that represent a type of research unit characterized by being " $[\ldots]$ relatively autonomous in their decision-making processes" (Ryan and Hurley, 2007: 346). This research considers the research groups as a community of researchers who work together in their approach to and development of research activities, sharing material and financial resources, and which are organized along the lines of the formal structure of the institution where the activity takes place (Perianes-Rodríguez et al., 2010).

Nowadays, research groups are more strategically driven, both internally and externally, than was previously the case; i.e. the emphasis is increasingly focused on resources, and research is being managed much more within the context of evaluative frameworks, which make performance more visible and also seek to assess it (Harvey et al., 2002; Boden et al., 1998). Robson and Shove (1999) also suggest that universities are endeavouring to organize and manage research more deliberately than ever before. Thus, it is the responsibility of the academic group to create adequate strategies and conditions that help to meet collective and individual research goals, such as high research performance (e.g. Amabile et al., 2004; Bland and Ruffin, 1992; Goodall, 2009; Van der 
Weijden, 2007; Van der Weijden et al., 2008). In this sense, Harvey et al. (2002) emphasize the importance of an entrepreneurial strategy to obtain high-achieving/highimpact research groups.

Entrepreneurial orientation has emerged as a major construct within the strategic management and entrepreneurship literature over the years (Morris and Kuratko, 2002). It characterizes a type of organization that adopts an entrepreneurial strategy (Wiklund, 1999). Various characteristics have come to be grouped alongside EO, including autonomy and competitive aggressiveness (Lumpkin and Dess, 1996; Lim \& Envick, 2011), although the characteristics receiving the most attention in the literature are: innovativeness, pro-activeness and risk propensity (Covin and Slevin, 1989; Lumpkin and Dess, 1996; Wiklund and Shepherd, 2003; Lim and Envick, 2011). Innovativeness reflects a tendency to engage in and support new ideas, innovation, experimentation, and creative processes (Lumpkin and Dess, 1996). Pro-activeness refers to a posture of anticipating and acting on future wants and needs in the marketplace, thereby creating a first-mover advantage vis-à-vis competitors (Lumpkin and Dess, 1996). Finally, risktaking is associated with a willingness to commit sizeable amounts of resources to projects where the outcomes are unknown and there is a reasonable chance of a costly failure (Miller and Friesen, 1978).

Across a variety of organization sizes and types, a stream of empirical research supports the direct effect of EO on performance (e.g. sales or profitability) (Smart and Conant, 1994; Zahra and Covin, 1995; Hughes et al., 2007; Van Doorn et al., 2013). Moreover, there is also some evidence to suggest that the effect of EO on performance is more pronounced in turbulent market environments as opposed to more benign environments 
(Baker and Sinkula, 2009; Covin and Slevin, 1989; McKee, Varadarajan and Pride, 1989).

The research group environment has certain characteristics that make it complex. For example, projects and research studies are typically organized between scientists from different universities and institutes who can be physically separated by thousands of miles (Travaille and Hendriks, 2010). This may result in an individual researcher becoming torn between the objectives of their own academic 'identity', the norms and requirements of their university department, and the scientific discipline (Garrett-Jones et al., 2010). Moreover, research is increasingly being organized into temporary limited and externally funded projects (König et al. 2013). This context suggests that a research group that, for example, faces problems in a different way (innovation), does not mind working under uncertain conditions (risk-taking), and keeps ahead of changes instead of just responding to them (pro-activeness), will be more likely to perform better.

On the other hand, the main task of a research group is to provide society with new knowledge. Indeed, a paper being accepted for publication indicates an acknowledgment of its original contributions to science from peers in the field (Lee et al., 2014). An individual or group creates outputs with high impact because they are more likely to produce novel outputs (Lee et al., 2014; Singh and Fleming, 2010). In order to perform well, it is important to have a pioneering and innovative orientation in the research group to identify new trends within the discipline and to be able to recognize new problems and new solutions for society (Harvey et al. 2002).

Based on this assumption, the first hypothesis is proposed: 
H1. There is a positive and direct relationship between entrepreneurial orientation and research group performance.

However, due to the very nature of the activity of a research group, it is difficult for any strategy to be effective if it is not accompanied by knowledge sharing between the group members. Thus, in the next section, a theoretical reflection on the mediating role that knowledge sharing may have on the relationship between EO and group performance is considered.

\section{The mediating role of knowledge sharing}

Knowledge-based theories argue that knowledge, competence and related intangibles have emerged as key drivers of high-performance in developed countries (Harvey et al. 2002). Individuals are a key element in creating new knowledge, but if this knowledge is not shared with other individuals or groups, it will have very little impact on the performance of the organization (Nonaka and Takeuchi, 1995; Madhavan and Grover, 1998; Ipe, 2003). The literature defines knowledge sharing as the act of placing knowledge possessed by an individual at the disposition of others within the organization, in such a way that it can be absorbed and utilized by them (Camelo-Ordaz et al., 2011). Previous work on knowledge sharing has focused on either organizational- or individuallevel analysis. However, little research has been focused on the consequences of knowledge sharing, where the variables affecting the group dynamics are included in the analysis (Liu et al., 2011). 
In research groups, researchers are knowledge workers, employed in the production of knowledge (Harvey et al. 2002). This means that managing knowledge plays a key role in mediating the influence or impact on many other factors within the group. In this sense, far from considering only the level of the workers, where the individual knowledge resides, it is important to go a step further and to look at the level of the group where the knowledge can increase the value within a university context. When the knowledge possessed by the group members is shared and transferred from one to another within a group, synergy occurs (Liu et al., 2011). Furthermore, research groups typically perform project-based work of a non-routine and complex nature. Such work requires effective coordination and the integration of ideas (Verbree et al., 2011), and the sharing of knowledge will thus play a key role here. Harvey et al. (2002) found that in order to improve performance in research groups, strong leadership consistently emerged as being associated with 'good practice', providing focus, direction, vision, coherence and ideas (Harvey et al. 2002).

Different authors have stressed the importance of providing facilities that enable interactions between researchers where they can share knowledge in order to obtain better group performance. Examples are internal research meetings, retreats and project meetings (e.g. Frederiksen et al., 2004; Mets and Galford, 2009). Along these lines the concept of group learning from Edmondson (1999) represents the process of reflection and action through which groups acquire, share, combine and apply knowledge (Argote et al., 1999). It is not enough that the group members have valuable and diverse knowledge; it is also vital that the knowledge is shared in order for new knowledge to be created (Lewis et al. 2005).

Thus, it is predictable that entrepreneurial orientation within a research group will be more effective when there is effective knowledge sharing within that same group. 
Srivastava et al. (2006) suggested that knowledge sharing in groups improves performance because of the beneficial effect it has on team coordination, specifically in the development of transactive memory, defined as the knowledge of 'who knows what' in a group (Wegner 1987; Srivastava et al., 2006). Similarly, Wong (2004) found a positive relationship between group learning and group efficiency from both outside and inside.

Taking on board entrepreneurial orientation implies the adoption of a set of distinct but related behaviours that include the qualities of innovativeness, pro-activeness, and risktaking (Pearce et al. 2010). For this to be translated into successful research group performance, researchers must create the conditions for the effective exploitation of new research opportunities. In general, successful opportunity exploitation requires a fullscale operation and implementation of new approaches (Choi and Shepherd, 2004). Assembling and combining dispersed, complementary knowledge can play a critical role in this process (De Clercq et al., 2010; Choi et al., 2008). Thus, the adoption of entrepreneurial orientation in a research group may lead to significant benefits, such as becoming global leaders in a particular field, but, at the same time, it may lead to a certain level of uncertainty. The study of new topics or the adopting of new approaches that may have received little attention up to that moment, can lead to the investment of resources and time into projects and research studies that do not have the expected results or may be considered irrelevant by the scientific and academic environment. Indeed, De Clercq et al. (2010) found that a firm's ability to leverage its entrepreneurial orientation (EO) into successful performance depends on internal social exchange processes that facilitate knowledge flows across functional departments. In this case, the quality of the knowledge 
exchange between academics will play a key role for the research group to convert its innovative, proactive, and risk-taking behaviour into a performance advantage.

Thus, the combination of entrepreneurial orientation and knowledge sharing can support a group situation for creating new knowledge that materializes in better group performance - see Figure 1. In this study, it is considered that in the specific case of academic research groups, conceptualised as communities practising "creative knowing", knowledge sharing becomes an essential mediator between entrepreneurial orientation and research group performance. Based on this assumption, we propose the following hypothesis:

H2. Knowledge sharing mediates the positive relationship between entrepreneurial orientation and academic research groups' performance.

Figure 1. The influence of entrepreneurial orientation on research groups' performance through academic knowledge sharing

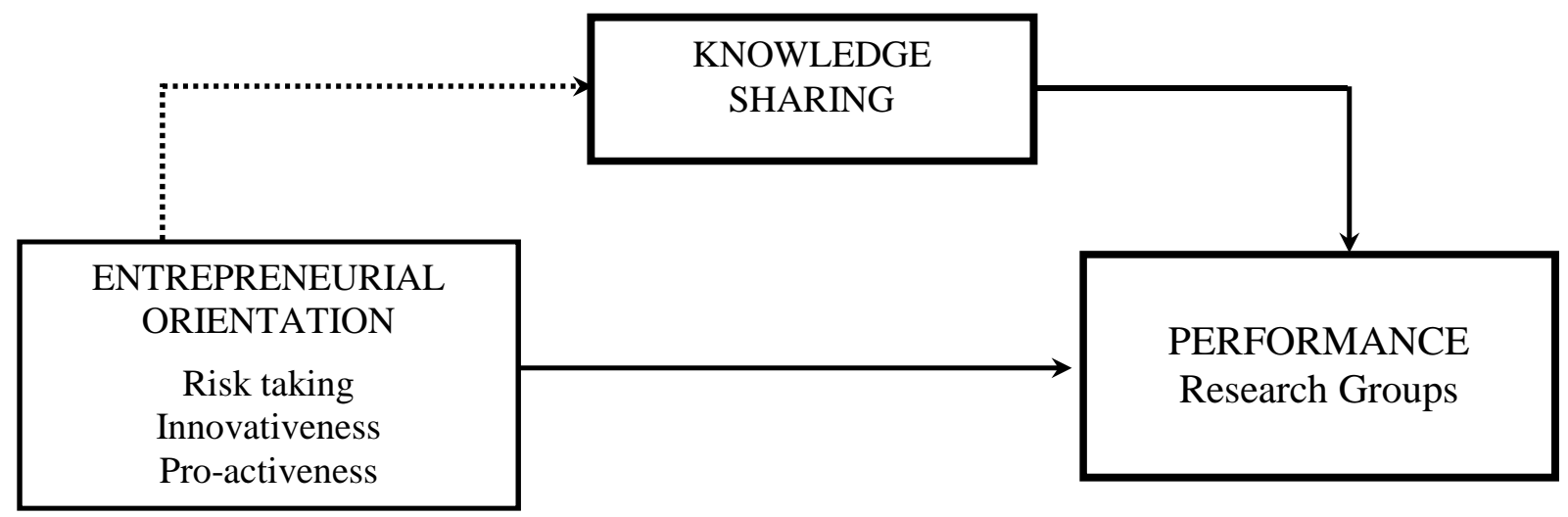

\section{Methodology}

3. 1 The research context 
This paper focuses on the entrepreneurial orientation of academic research groups and, in particular, on its effect on their scientific production at Las Palmas de Gran Canaria University. In order to promote the transfer of knowledge to society, these aspects are extremely important for a medium-sized university located in an ultra-peripheral region of the EU, with 1,500 lecturers and over 20,000 students.

The Canary Islands are an ultra-peripheral region of the EU and its economy is focused on the tourism industry and the commercial sector. The private firms in the region are characterized by a low level of investment in $R \& D$ activities, therefore the Canary Islands could be categorised as a region of low technological intensity. In this sense, one of the missions of Las Palmas de Gran Canaria University is to contribute to the region's economic development, by adapting its research to the current leading sectors of the regional economy. Thus, the outsourcing of $R \& D$ activities to the universities is one of the channels most used by firms in the Canaries for knowledge acquisition.

In order to promote innovation and knowledge generation in this kind of region, the European Regional Development Fund (ERDF) (2007-2013) fosters systematic relations between firms and universities, which take into account local needs. More specifically, the European Programme for the Canary Islands emphasises the need to improve the transfer to and absorption by the Canarian firms of the knowledge outputs generated by the Canarian universities. The programme has therefore encouraged the creation of research groups to promote the scientific production and transfer of knowledge.

\subsection{Sample}

In order to test the proposed hypotheses, an empirical study was conducted within a Spanish university, taking into account all the research groups (157) existing in 2010. In Spain, in article 40.2 of the Organic Law of Universities (LOU) of 24 December 2001, research groups are mentioned as being the basic units for undertaking research. Thus, as 
of the year 2003, research groups at Spanish universities, and specifically so at the University of Las Palmas de Gran Canaria, are constituted formally. At this particular university, the groups should be formed by a minimum of three members, of which at least one member is a civil servant. Furthermore, a researcher may only belong to one group.

The annual reports published by the university were the source of information used for the empirical study. The number of groups during the study period varies from 149 in 2006 to 160 in 2008, with the number of observations in the period reaching 617 . This upward trend reflects the creation of new groups over the period of analysis. The research groups at this Spanish University are characterized by being made up of $71.56 \%$ Ph.Ds.; $61.14 \%$ of researchers are men; 82.87 of the members of the teams are teaching staff; $53.35 \%$ are public servants; and $4.93 \%$ of researchers are from other universities. These groups belong to different knowledge areas: humanities (an average of 34 groups); social science (49); experimental (51); technological (23) and health science (36).

Primary and secondary sources of information were combined to obtain the data. In this sense, the research groups' performance and the control variables were obtained by information given by the Vice Chancellor for Research at the university, based on the Annual Research Reports. The data to measure the entrepreneurial orientation and knowledge sharing was collected via a survey carried out among members of all research groups. This data collection strategy reduced the possibility of percept-percept bias, because the data for each stage of our model was collected from a different source.

A pre-test was performed by sending the questionnaire to academic researchers selected from different knowledge areas. After including their suggestions, some questions were removed; others reformulated or added. The surveys and a personalized cover letter were sent out to the institutional email address of all members of each research group. Two 
weeks after the initial mailing, we sent reminder notes to those researchers that had not yet answered. Then, in order to increase the number of responses and to follow the recommendations of many researchers, hard-copy surveys were sent by mail to those who had not yet responded. We compared early and late respondents and hardcopy and e-mail respondents in terms of demographic characteristics such as knowledge area, gender, etc. (Alexiev et al., 2010). These comparisons did not reveal any significant differences, indicating that differences between respondents were not related to non-response bias.

The research groups included 1060 researchers belonging to five different knowledge areas. The response rate was $75.16 \%$, based on the number of research groups (we received responses from 118 groups) and $30.19 \%$ with respect to the number of researchers (320 researchers completed the survey). However, five questionnaires were eliminated as they were incomplete. Furthermore, and given that for the development of this study the research group is considered the unit of analysis, it was necessary for at least 2 of the members of the research group to have completed the questionnaire correctly in order to retain the data for that group. As a result, another 31 questionnaires were discarded. Therefore, the final sample was made up of 284 researchers (final response rate $26.79 \%$ ) that belonged to 87 research groups (final response rate $55.41 \%$ ).

Regarding the final sample of researchers, approximately $65 \%$ of group members are men, 52\% are between 40 and 50 years old, and $40 \%$ of the academics have been at the university between 10 and 20 years, whereas the other $46 \%$ have been there for more than 20 years. Furthermore, a total of $62 \%$ of the respondents were civil servants $(14 \%$ professors and $48 \%$ senior lecturers).

The number of members per research group ranged between 3 and 58 and the average group size in the sample was 11 . The level of response within each group was different, but on average $46 \%$ of those in the groups responded. Thus, the number of respondents 
per group ranged from 2 to 12 , with an average of 3.26 researchers per group. In addition, $26 \%$ of the groups belong to social and law sciences, followed by arts and humanities $(23 \%)$ and health sciences (18\%). Finally, $16 \%$ of the groups belong to the knowledge area of science and the same amount to the area of engineering and architecture.

\subsection{Variables}

Performance of Research Groups. This variable was measured by the number of published articles per research team within the study period (e.g., Stvilia et al., 2011; Cummings et al., 2013). The number and quality of peer-reviewed publications are regarded as the most important research performance criterion in academia (Braun et al., 2013), As Ou et al. (2012) and Simsek et al. (2013) indicate, the impact factor of a journal is used as an indicator of the journal's quality and provides a quantifiable way of measuring publication success. Therefore, the performance of the academic research groups was operationalised as the total number of articles published by each group during the period 2006-2010 in journals belonging to Thomson Reuters ISI Web of Science database (hereafter ISI articles). Other previous studies have also measured research group performance using the number of articles (Braun et al., 2013; Kao and Hung, 2008; Lissoni et al., 2011; Van der Weijden et al., 2008). Moreover, a second variable (Productivity) is calculated by dividing the number of ISI articles of each group by the average number of group members for the period (Defazio et al., 2009).

Entrepreneurial orientation. This variable was measured with a 10 -item scale developed to reflect the innovativeness, pro-activeness and risk propensity of the research group (Covin and Slevin, 1989; Stull and Singh, 2005). A 7 point Likert scale was used, where 1 represented "strongly disagree" and 7 "strongly agree". Items from previous studies 
were used and adapted to the context of academic research groups (see Appendix I). In order to adapt the scale to the research group context, each item was carefully analyzed in order to make it consistent with the research task and context. For example, in the risktaking scale, the items asked about conditions of uncertainty or possibility of failure. These situations are circumstances that individuals have to face when they research.

A sample item from innovativeness is "Members of my research team usually find new ways to do the tasks"; from pro-activeness, "My research team is ahead of the changes rather than reactive to them"; and from risk-taking, "My research team does not mind working in uncertain situations if there is a reasonable likelihood of obtaining benefits from it". In order to reduce the dimension of the scale, a confirmatory factor analysis with varimax rotation was carried out, reflecting the existence of the three dimensions expected (innovativeness, pro-activeness and risk propensity). They accounted for $81.10 \%$ of the total variance. All loadings exceeded 0.70 . In addition, the overall scale demonstrated acceptable internal consistency (Cronbach alpha of 0.946). ). Moreover, the Cronbach's alpha of each construct (EO_Innovativeness, EO_Proactiveness, EO_Risk taking) individually indicates their reliability.

Knowledge Sharing. Knowledge Sharing was measured with a 10-item scale, which was adapted from Hsu et al. (2007), Chow and Chan (2008) and Liu et al. (2011). Responses were made on a 7 point scale anchored by $1=$ strongly disagree and $7=$ strongly agree (see Appendix I). In order to analyse the convergent validity and the reliability of the constructs, we conducted a confirmatory factor analysis, which allowed us to test the unidimensionality of the scale. The result was a single factor with an eigenvalue of nearly eight, accounting for $77.217 \%$ of the total variance. All loadings exceeded 0.70 . The $10-$ 
item measure of knowledge sharing used in this study yielded an acceptable internal consistency $(\alpha=0.971)$.

Control Variables. A review of the literature and consideration of the research context suggested the need to control several variables in the model in order to establish the robustness of the results. Group size is controlled by the average number of members of each academic research group. On the one hand, a larger size group may generate a higher number of publications; but on the other, it may suffer problems of internal coordination and conflict, for this reason this variable was included in a non-linear way. In academic research, doctoral dissertations often represent a starting point for obtaining future articles and are a variable linked to the knowledge area. In this study, we also consider as a control variable the number of dissertations presented during the study period by each research group, adjusted by the average for the knowledge area. The percentage of members holding a Ph.D. in each group and the percentage of civil servants and researchers from other universities in each group were also included as control variables in line with previous studies. The knowledge area which the research group is linked to is considered through five dummy variables, which adopt the value 1 if the group belongs to a specific area: arts and humanities, social and law sciences, sciences, health sciences and engineering and architecture. The knowledge area omitted from the models is arts and humanities. These variables attempt to control the cultural or idiosyncratic issues and the common practices of groups belonging to the same area of knowledge.

The variables used are summarized in Appendix II.

\section{Calculation of Intergroup Agreement}

In this study, we aggregated member ratings of knowledge sharing and entrepreneurial orientation scales to the group level. The fundamental reason was that the hypotheses 
identified the unit of analysis as the research group. However, the aggregation meant that the perceptions of members in each group had to be reasonably homogeneous. To justify data aggregation, researchers must show that there is sufficient within-group homogeneity and that there is sufficient dissimilarity between groups. Due to the fact that entrepreneurial orientation and knowledge sharing were measured by multiple items, in order to estimate the intragroup agreement score $\left(\mathrm{r}^{*} \mathrm{wg}(\mathrm{j})\right)$ of the academics' ratings within each group we used James, Demaree and Wolf's (1984) procedure, subsequently modified by Lindell et al. (1999), whose values vary between 0 (total disagreement) and 1 (total agreement). As Waldman et al. (2004:367) state “[...] the Lindell et al. procedure does not inflate results, as compared to its predecessors". The mean (median) r*wg(j) values across the 87 groups were $0.72(0.84)$ for OE_risk-taking, $0.86(0.90)$ for OE_innovativeness, $0282(0.89)$ for OE_pro-activeness, and, $0.93(0.95)$ for knowledge sharing. The scores were higher than 0.70 , an often cited cut off point, and could be considered as indicative of a good level of agreement within a group (Bresman 2010). In summary, the individual-level data of the study is suitable for group-level aggregation.

\section{Analyses}

In this study, we employ simultaneous equation models that are estimated using threestage least squares (3SLS). In order to test the direct effect of entrepreneurial orientation on the performance of the research group, as well as the indirect effect of the same dimensions through knowledge sharing, we specify a system of two simultaneous equations.

The first equation is related to research group performance and includes the effect of one endogenous variable (knowledge sharing). In this equation, the three factors of entrepreneurial orientation are the key explanatory variables of interest, while we also control several characteristics that affect research group performance. The second 
equation examines the endogenous variable (knowledge sharing) and includes a set of control variables. Entrepreneurial orientation dimensions are also the key explanatory variables of interest.

Our system of equations presents an endogenous variable (knowledge sharing). Thus, the estimation by Ordinary Least Squares (OLS) could obtain biased or inconsistent estimators. This is why, in order to test the hypotheses proposed, the model was estimated by applying the simultaneous equations approach using 3SLS. There are two estimation methods for a system of simultaneous equations: least squares in two stages (2SLS) or in three stages (3SLS). The latter estimates all equations of the system at the same time, taking into consideration all the restrictions. Greene (2000) indicates that this method is better than the estimation methods in two stages; especially for smaller sized samples. Alcock et al. (2012) point out that estimation by 3SLS is more efficient. Moreover, the 3SLS method takes the cross-equation error correlations into account to improve large sample efficiency. The estimation of the model is carried out with the econometric programme STATA 11.

\section{Results}

Firstly, this section summarizes the results of the descriptive analysis. Table 1 shows that the average number of articles published in journals included in the ISI by research groups during the period of study is 20.4, whereas the median is 12 articles. As shown in the table, this variation is due, in part, to the existence of two research groups with no publications at all during those years, and others with a high number of published articles, as well as the effect of the knowledge area itself. In this respect, the data also reveals significant differences between ISI articles depending on the knowledge area. Thus, the research groups that belong to the health science and science areas are the ones that published the greatest number of articles (26 and 23 articles on average). In addition, the 
groups belonging to the knowledge area of engineering and architecture published 4.5 articles and those from arts and humanities had 9.5 publications in median terms.

[Insert Table 1 above here]

Similarly, significant differences are observed between the research groups belonging to the different areas with regards to knowledge sharing. Specifically, the groups from the areas with the least number of articles present the lowest values for the knowledge-sharing variable. Furthermore, in mean terms, the groups with the highest number of publications share more knowledge (see Table 1). The data also shows differences in the value of the variable that measures entrepreneurial orientation based on the knowledge area that the research group belongs to.

The data in Table 2 shows that there are significant differences in the scientific production of research groups as well as knowledge sharing, taking into account the entrepreneurial orientation dimensions. Subsequently, a research group with a high value of EO proactiveness (above its average) has published 27.39 articles on average, whereas another group who has a low EO pro-activeness (below its average) has published 13.26 articles, on average. In addition, research groups with higher levels of entrepreneurial orientation dimensions (innovativeness, pro-activeness and risk-taking) share more knowledge. These preliminary results are consistent with the proposed hypotheses regarding the relevance of the entrepreneurial orientation dimensions of research groups.

[Insert Table 2 above here]

Table 3 summarizes the descriptive statistics and the correlations matrix of all the variables. In the correlation matrix, significant correlations are observed between the variables that represent research group performance, knowledge sharing and 
entrepreneurial orientation dimensions. Regarding the explanatory variables, there are no multi-collinearity problems as the VIF (Variance Inflation Factor) values are less than five in all cases.

[Insert Table 3 above here]

Table 4 presents the results obtained from the 3SLS estimation of the simultaneous system of two equations that allows for the analysis of the mediating effect of knowledge sharing in the relationship between the entrepreneurial orientation dimensions and the performance of the research groups. The dependent variable in the first equation is the number of ISI articles and the explanatory variables include knowledge sharing, entrepreneurial orientation factors and a set of control variables. In the second equation, the dependent variable is knowledge sharing, whereas the explanatory variables are the entrepreneurial orientation dimensions and a set of control variables.

The results of equation 1 reveal that there is a significant but negative direct effect of two entrepreneurial orientation dimensions on the research group performance $(B=-20.26$ $\mathrm{p}<0.05$ for EO_innovativeness, and $\beta=-26.75 \mathrm{p}<0.05$ for $\mathrm{EO}$ _risk taking), but there is no significant direct effect of EO_pro-activeness. Contrary to our expectations, these results do not support Hypothesis 1.

Regarding Hypothesis 2, which postulated that knowledge sharing mediates between entrepreneurial orientation and research group performance (indirect effect), the results shown in Table 4 (equation 1 and 2) reflect that all the dimensions of entrepreneurial orientation have a positive and significant effect on those groups that share knowledge (equation $2, \beta=0.401 \mathrm{p}<0.01$ for EO_innovativeness, $\beta=-0.197 \mathrm{p}<0.01$ for EO_proactiveness, and $B=0.475 \mathrm{p}<0.01$ for EO_risk taking). In this respect, the results show 
that the research groups with better entrepreneurial orientation share more knowledge. The results of equation 1 also reveal a positive and significant effect of knowledge sharing on the research group performance $(\beta=59.417, \mathrm{p}<0.01)$; that is, the groups that share more knowledge among members publish a higher number of articles in ISI journals. Therefore, hypothesis 2 is supported.

[Insert Table 4 above here]

As far as the control variables are concerned, the results show (see Table 4) that the knowledge area to which the research groups belong has an effect on group knowledge sharing, as does the existence of researchers from other universities. Moreover, it could be observed that the size of the research group affects the group's knowledge sharing as well as the publication of articles by the groups in a non-linear way. The results also show a positive and significant relationship between the percentage of Ph.D. members in the group and the number of articles per research group. In the same way, a positive and significant relationship between the number of doctoral dissertations and the research groups' performance is observed.

To analyse the robustness of the results, an additional analysis that redefined the dependent variable was carried out. In this sense, model I was re-estimated replacing the dependent variable in equation 1 (ISI articles) with research group productivity. The results of model II do not differ from those obtained for model I (see Table 4), and there is a significant but negative effect of two entrepreneurial orientation dimensions (proactiveness and risk-taking) on the research group's productivity. Similarly, knowledge sharing has a positive and significant effect on performance. Therefore, the results of model II also show that the three entrepreneurial orientation dimensions have a significant and positive effect on the knowledge that the research groups shared. 
Finally, the direct effect, as well the total effect of the entrepreneurial orientation dimensions, is presented in Table 5, considering the mean and median value of the EO dimensions. The data reveals that the direct effect of those dimensions on ISI articles is negative (-0.1745 and -0.3290). However, the total effect of EO dimensions on the research group's performance is positive.

\section{[Insert Table 5 above here]}

\section{Discussion of the results}

With the purpose of understanding the relationship between entrepreneurial orientation and research group performance, the focus of this study is on analyzing the role played by knowledge sharing as a mediator in this relationship. More specifically, the aim of this paper has been to explain and to test empirically how EO contributes to explaining academic research group performance directly and through knowledge sharing.

One of the main relevant findings of this research is the negative direct relationship between EO and research group performance and, specifically, in relation to innovativeness and risk taking. Along these lines, Lee et al. (2014) argued that, in scientific groups, very novel outputs are sometimes not so useful if they cannot be integrated into existing paradigms and techniques. Sometimes, more conventional outputs are more popular, resulting in high impact. Therefore, creating novel outputs and producing outputs with a high impact may have different mechanisms in team science (Fiore 2008).

With regards to academic research, the editors and reviewers of the different journals play the role of individuals who have to accept this innovation and, in particular, to perceive the real contribution of the research to the existing knowledge. There are different factors 
that can affect this, such as, for example, being familiar or not with the process explained. A proposed new methodology for a particular field can help to promote a perception of and acceptance of innovation (Gruner and Homburg 2000), and the attitude held by the individual towards innovation will also have an effect (Karmal 2006). Some literature in psychology suggests the existence of a bias against novelty, to the extent that it may prove difficult to obtain recognition for novel ideas and they may not be taken on board by others easily (Mueller et al. 2011).

The research findings suggest that if the relationship between EO and research group performance is mediated by knowledge sharing, then the effect is positive. The results support the argument that knowledge needs to be shared between the members of the group in order for innovativeness, risk taking and pro-activeness to have a positive effect on group performance (De Clercq et al. 2010). If this does not happen, the effect is quite the opposite. Thus, high performance research groups display the characteristics of an entrepreneurial group, but not under all conditions.

Like in other teams, researchers' productivity depends on the perception of a collaborative climate with cooperation and communication between the members (Tekleab et al. 2009). One of the main reasons is that the knowledge sharing processes that occur within the research team allow their members to access new 'knowledge-recombinant opportunities for the creation process' (Rotolo and Petruzzelli 2013: 651). The feedback and synergies between the team members can help them to recognize potential weaknesses in their entrepreneurial strategies and turn them into better accepted ideas by the academic community. Indeed, Travaille and Hendriks (2010) highlight that it takes many years to build up the skills and experience needed for publishing. This kind of experience and the 
associated skills could be part of the knowledge sharing activity within the team, thus leading to higher levels of an individual researcher's success in getting a study published.

Finally, in the context of Canadian-based firms, the study of De Clercq et al. (2010) demonstrated that EO- performance relationship is stronger when the organization's social context comes closer to an "ideal" configuration of procedural justice, trust, and organizational commitment that is most conducive to knowledge exchange within the organization. In this line, Walter et al. (2006) found that networking capabilities moderate the relationship between EO and organizational performance. They argued that "a spinoff's organizational propensities and processes that enhance innovation, constructive risk taking, and pro-activeness in dealing with competitors per se do not enhance growth and secure long-term survival" (Walter et al. 2006: 558). Thus, networking capabilities strengthen the relationship between EO and spin-off performance.

Our research goes further and concludes that in the case of a pure knowledge production activity, like a research group, the relationship can even prove to be negative without the existence of activities like sharing research experience and results with others researchers. As far as new research opportunities or projects with a high degree of innovation are concerned, the suggestions and feedback from other members of the group will help to recognize and discriminate the better options and to improve the research potential.

\section{Conclusions}

The main contribution of this research is that it is the first to provide empirical evidence of the role played by the combination of entrepreneurial orientation and knowledge sharing in the performance of a research group. In the question under study, an 
entrepreneurial group will not be effective and may even be negative for the production of new knowledge, if the members of the groups do not have a knowledge sharing culture and process in place.

This paper has contributed to the field in several ways. It represents a significant contribution by using research groups as a unit of analysis, whereas the majority of previous studies centred on the analysis of individual researchers. This research therefore has important practical implications to the extent that it can help research groups of public and private organizations to determine what their optimum research strategy should be in order to improve performance. Our results suggest that groups can maximize their performance by sharing knowledge and developing an entrepreneurial strategy.

Moreover, this study provides further support for designing policies to hold up academic research. Specifically, it shows that it is important to use mechanisms that promote the combination of entrepreneurial strategies and knowledge sharing practices. In this sense, it is crucial to facilitate knowledge sharing among researchers and to implement policies that promote cooperation between the different agents involved in the process.

Despite the contributions stated, this research presents some limitations that should be considered for future studies. Firstly, the analysis was carried out in one Spanish university context and therefore cannot be generalized. However, having considered all the research groups at the university, with their different backgrounds and research interests, we think that the study has greater validity regarding the generalization of the findings. In spite of the fact that it is true that national cultures influence the way a group works and shares knowledge (Ford and Chan, 2003), the internationalization of the academic profession, and the ways of measuring the impact of research, play an important role in the homogenization of the processes within research groups. This limitation thus 
leads us to consider the need to use a sample with research groups from universities from different countries in future studies. Secondly, as this is the first study that analyses the mediating role of knowledge sharing in the relationship between EO and research group performance, a deeper understanding of the phenomena could be gained through a case study, which would help to understand the causes and contexts of these results (Harvey et al., 2002).

\section{ACKNOWLEDGEMENTS}

We would like to acknowledge the financial support received through the Research Project of the Ministry of Education and Science, ECO2010-201139 ECON. Thanks are also due to the editors and two anonymous referees for their valuable assistance in improving the manuscript. Any errors or omissions remain the responsibility of the authors. 


\section{References}

Alavi, M. \& Leidner, D. (2001). Knowledge management and knowledge management systems: Conception, foundations and research issues. MIS Quarterly, 1, 107-136.

Amabile, T. M., Schatzel, E. A., Moneta, G. B., \& Kramer, S. J. (2004). Leader behaviors and the work environment for creativity: Perceived leader support. Leadership Quarterly, $15(1), 5-32$.

Argote L, Gruenfeld D, \& Naquin C. 1999. Group learning in organizations. In Groups at Work: Advances in Theory and Research, Turner ME (ed.). Lawrence Erlbaum: Hillsdale, NJ

Baker, W.E. \& Sinkula, J.M. (2009) The Complementary Effects of Market Orientation and Entrepreneurial Orientation on Profitability in Small Businesses. Journal of Small Business Management, 47(4), 443-464

Bercovitz, J. \& Feldmann, M. (2006). Entrepreneurial Universities and Technology Transfer: A Conceptual Framework for Understanding Knowledge-Based Economic Development. Journal of Technology Transfer, 31, 175-188.

Bland, C. J., \& Ruffin, M. T. (1992). Characteristics of a productive research environment: literature review. Academic Medicine, 67(6), 385-397.

Boden, R., Gummett, P., Cox, D. \& Barker, K. (1998). Men in white coats ... men in grey suits: New public management and the funding of science and technology services to the UK Government, Accounting, Auditing \& Accountability Journal, 11(3), 267-291.

Brettel, M. \& Rottenberger, J.D. (2013). Examining the link between Entrepreneurial Orientation and Learning Processes in Small and Medium-Sized Enterprises. Journal of Small Business Management, 51(4), 471-490.

Cabrera, A. \& Cabrera, E.F. (2002). Knowledge-sharing dilemmas. Organization studies, 23, 687-710.

Camelo-Ordaz, C.; García-Cruz, J.; Sousa-Ginel, E. \& Valle-Cabrera, R. (2011). The influence of human resource management on knowledge sharing and innovation in Spain: the mediating role of affective commitment. The International Journal of Human Resource Management, 22(7), 1442-1463.

Choi, Y.R. \& Shepherd, D.A. (2004). Entrepreneur's decision to exploit opportunities. Journal of Management, 30, 377-395.

Choi, Y.R.; Lèvesque, M. \& Shepherd, D.A. (2008). When should entrepreneurs expedite or delay opportunity exploitation. Journal of Business Venturing, 23, 333-355.

Covin, J.G. \& Lumpkin, G.T. (2011). Entrepreneurial orientation theory and research: Reflections on a needed construct. Entrepreneurship Theory \& Practice, 35(5), 855-872. 
Covin JG, \& Slevin DP. (1989). Strategic management of small firms in hostile and benign environments. Strategic Management Journal, 10(1), 75-87.

Cummings, J.N., Kiesler, S., Zadeh, R.B., \& Balakrishnan, A.D. (2013). Group heterogeneity increases the risks of large group size: A longitudinal study of productivity in research groups. Psychological Science, 24(6), 880-890.

De Bellis, N., (2009). Bibliometrics and Citation Analysis: from the Science Citation Index to Cybermetrics. Lanham, MD: Scarecrow Press.

De Clercq, D., Dimov, D. \& Thongpapanl, N. (2010). The moderating impact of internal social exchange processes on the entrepreneurial orientation-performance relationship. Journal of Business Venturing, 25(1), 87-103.

Defazio, D., A. Lockett \& M. Wright (2009). Funding incentives, collaborative dynamics and scientific productivity: Evidence from the EU framework program. Research Policy, 38(2), 293-305.

Edmondson, A. (1999). Psychological safety and learning behavior in work teams. Administrative Science Quarterly, 44, 350-383.

Etzkowitz, H., Webster, A., Gebhardt, C. \& Cantisano Terra, B.R. (2000). The future of the university and the university of the future: evolution of ivory tower to entrepreneurial paradigm. Research Policy, 29(2): 313-330.

Ford, D.P. and Chan, Y.E. (2003). Knowledge sharing in a multi-cultural setting: a case study. Knowledge Management Research \& Practice, 1(1), 11-27.

Frederiksen, L. F., Hemlin, S., \& Husted, K. (2004). The role of knowledge management in R\&D: a survey of Danish R\&D leaders' perceptions and beliefs. International Journal of Technology Management, 28(7-8), 820-839.

Garrett-Jones, S.; Turpin, T. \& Diment, K. (2010). Managing competition between individual and organizational goals in cross-sector research and development centers. Journal of Technology Transfer, 33, 527-546.

Goodall, A. (2009). Highly cited leaders and the performance of research universities. Research Policy, 38, 1079-1092.

Gruner, K.E. \& Homburg, C. (2000). Does Customer Interaction Enhance New Product Success? Journal of Business Research, 49(1), 1-14.

Harvey, J., Pettigrew, A. \& Ferlie, E. (2002). The determinants of research group performance: towards mode 2?. Journal of Management Studies, 39(6), 747-73.

Hughes, M.; Hughes, P. \& Morgan, R.E. (2007). Exploitative learning and entrepreneurial orientation alignment in emerging young firms: Implications for market and response performance. British Journal of Management, 18, 359-375. 
Hulsheger, U. R., Anderson, N., \& Salgado, J. S. (2009). Team-level predictors of innovation at work: A comprehensive meta-analysis spanning three decades of research. Journal of Applied Psychology, 94, 1128-1145.

Ipe, M. 2003. Knowledge Sharing in Organizations: A Conceptual Framework. Human Resource Development Review, 2, 337-359.

Jackling, B. J., \& Johl, S. (2009). Board structure and firm performance: Evidence from India's top companies. Corporate Governance: An International Review, 17, 492-509.

Kamal, M.M. (2006). IT innovation adoption in the government sector: identifying the critical success factors. Journal of Enterprise Information Management, 19(2), 192 - 222.

Kao, C. \& Hung, H.T. (2008). Efficiency analysis of university departments: An empirical study. Omega-The International Journal of Management Science, 36, 653-664.

Kirby, D.A. (2002). Creating Entrepreneurial Universities: A consideration. Working Paper from the School of Management, University of Surrey, Guildford, UK.

Kirby, D.A. (2006). Creating Entrepreneurial Universities in the UK: Applying Entrepreneurship Theory to Practice. Journal of Technology Transfer, 31(5): 599-603, 2006.

König, B., Diehl, K., Tscherning, K, \& Helming, K. (2013). A framework for structuring interdisciplinary research management. Research Policy, 42, 261-272.

Lauring, J. \& Selmer, J. (2013). Diversity attitudes and group knowledge processing in multicultural organizations. European Management Journal, 31, 124-136.

Lee, Y.N., Walsh, J.P. \& Wang, J. (2014). Creativity in scientific teams: Unpacking novelty and impact. Research Policy, doi:10.1016/j.respol.2014.10.007

Lewis, K.; D. Lange, \& Gillis, L. (2005) Transactive memory systems, learning, and learning transfer. Organization Science, 16(6), 581-598.

Lim, S., \& Envick, B. R. (2011). Gender and entrepreneurial orientation: a multicountry study. International Entrepreneurship and Management Journal, 7,1-15.

Liu, Y.; Keller, R.T. \& Shih, H.A. (2011). The impact of team-member exchange, differentiation, team commitment, and knowledge sharing on $R \& D$ project team performance. R\&D Management, 41(3), 274- 287.

Lumpkin, G.T. \& Dess, G.G. (1996). Clarifying the entrepreneurial orientation construct and linking it to performance. Academy of Management Review, 21(1), 165-172.

Madhavan, R. \& Grover, R. 1998. From Embedded Knowledge to Embodied Knowledge: New Product Development as Knowledge Management. Journal of Marketing, 62, 1-12. 
Matsumoto, M., Yokota, S., Naito, K. and Itoh, J. (2010), Development of a model to estimate the economic impacts of $R \& D$ output of public research institutes. R\&D Management, 40, 91-100.

Mets, B., \& Galford, J. A. (2009). Leadership and management of academic anesthesiology departments in the United States. Journal of Clinical Anesthesia, 21(2), 83-93.

McKee, D.O., Varadarajan, P.R. \& Pride, W. M. (1989). Strategic Adaptability and Firm Performance: A Market-Contingent Perspective. Journal of Marketing 53(3), 21-35.

Miller, D. \& Friesen P.H. (1978). Archetypes of strategy formulation. Management Science, 24, 9, 921-933.

Morris, M.H. \& Kuratko, D.F. (2002). Corporate entrepreneurship. Fort Worth, TX: Harcourt College Publishers.

Nederhof, A.J., \& van Raan, A.F.J. (1993). A bibliometric analysis of six economics research groups: a comparison with peer review. Research Policy 22, 353-368.

Neves, P. \& Caetano, A. (2009). Commitment to change: Contributions to trust in the supervisor and work outcomes. Group \& Organization Management, 34:623.

Nonaka, I. \& Takeuchi, H. (1995). The Knowledge-Creating Company, New York: Oxford University Press.

Pearce II, J.A.; Fritz, P., \& Davis, P.S. (2010). Entrepreneurial orientation and the performance of religious congregations as predicted by rational choice theory. Entrepreneurship Theory and Practice, 34(1), 219-248.

Perianes-Rodríguez, A., Olmeda-Gómez, C., \& Moya-Anegón, F. (2010). Detecting, identifying and visualizing research groups in co-authorship networks. Scientometrics, 82(2), 307-319.

Rauch, A.; Wiklund, J.; Lumpkin, G.T. \& Frese, M. (2009). Entrepreneurial orientation and business performance: An assessment of past research and suggestions for the future. Entrepreneurship Theory \& Practice, 33(3), 761-787.

Robson, B. and Shove, E. (eds) (1999) Interactions and Influence: Individuals and Institutions, summary report of six pilot studies commissioned by the ESRC. ESRC, Swindon.

Rubiralta, M.; \& Vendrell, M. (2002). Hacia un Nuevo Modelo de Transferencia de los Resultados de la Investigación Universitaria. Revista Madri+d, Monografía, 5, 7-14.

Ryan, J. C. \& Hurley, J. (2007). An empirical examination of the relationship between scientists' work environment and research performance. R\&D Management, 37, 345-354.

Singh, J., \& Fleming, L. (2010). Lone inventors as sources of breakthroughs: Myth or reality? Management Science, 56(1), 41-56. 
Smart, D. T., \& Conant, J. S. (1994). Entrepreneurial Orientation, Distinctive Distinctive Marketing Competencies and Organizational Performance. Journal of Applied Business Research 10(3), 28-38.

Spender, J. C., \& Grant, R. M. (1996). Knowledge and the firm: Overview. Strategic Management Journal, 17, 5-9.

Srivastava, A., Bartol, K.M. \& Locke, E.A. (2006). Empowering leadership in management teams: effects on knowledge sharing, efficacy and performance. Academy of Management Journal, 49(6), 1239-1251.

Stull, M. \& Singh, J. (2005). Intrapreneurship in nonprofit organisations: examining the factors that facilitate entrepreneurial behaviour among employees. Working Paper Case Western Reserve University.

Stvilia, B., Hinnant, C.C., Schindler, K., Worrall, A., Burnett, G., Burnett, K., Kazmer, M.M., \& Marty, P.F. (2011). Composition of scientific teams and publication productivity at a National science lab. Journal of the American Society for Information Science and Technology, 62(2), 270-283.

Tijssen, R.J.W. (2006). Universities and industrially relevant science: Towards measurement models and indicators of entrepreneurial orientation. Research Policy, 35, $1569-1585$.

Travaille, A.M. \& Hendriks, P.H.J. (2010) What keeps science spiralling? Unravelling the critical success factors of knowledge creation in university research. Higher Education, 59(4), 423-439.

Tsai, W. (2001). Knowledge transfer in intra-organizational networks: Effects of network position and absorptive capacity on business unit innovation and performance. Academy of Management Journal, 44, 996-1004.

Uzzi, B., Mukherjee, S., Stringer, M., \& Jones, B. (2013). Atypical Combinations and Scientific Impact. Science, 342(6157), 468-472.

Van der Weijden, I. (2007). In search of performance. Research management within the Dutch public medical and health sector. Amsterdam: Vrije Universiteit.

Van der Weijden, I., De Gilder, D., Groenewegen, P., \& Geerling, M. (2008). Organizational culture, performance and career choices of Ph.D.s: A case study of Dutch Medical Researchers. Higher Education Policy, 21, 305-321. 
Van Doorn, S.; Jansen, J.J.P.; Van den Bosch, F.A.J. \& Volberda, H.W. (2013). Entrepreneurial Orientation and Firm Performance: Drawing attention to the senior team. Journal of Product Innovation Management, 30(5), 821-836.

Van Looy, B., Callaert, J. \& Debackere, K. (2006). Publication and patent behavior of academic researchers: Conflicting, reinforcing or merely co existing? Research Policy, 35, 596-608.

Verbree, M.; Horling, E.; Groenewegen, P.; VanderWeijden, I. \& Besselaar, P. (2011). Addressing leadership and management of research groups: a multivariate study. Working paper. Rathenau Instituut, Den Haag.

Walter, A., Auer, M. \& Thomas Ritter, T. (2006). The impact of network capabilities and entrepreneurial orientation on university spin-off performance. Journal of Business Venturing, 21, 541- 567.

Wang, E.T.G.; Ying, T.; Jiang, J.J. \& Klein, G. (2006). Group cohesion in organizational innovation: An empirical examination of ERP implementation. Information and Software Technology, 48(4), 235-244.

Wegner, D.M. (1987). Transactive memory: A contemporary analysis of the group mind. In B. Mullen \& G.R. Goethals (Ed.), Theories of group behavior (pp. 185-208). New York: Springer-Verlag.

Wheelan, S., Murphy, D., Tsumura, E., \& Fried Kline, S. (1998). Member perceptions of internal group dynamics and productivity. Small Group Research, 29(3), 371-393.

Wheelan, S. \& Tilin, F. (1999). The relationship between faculty group development and school productivity. Small Group Research, 30(1), 59-81.

Wiklund J. (1999). The sustainability of the entrepreneurial orientation-performance relationship. Entrepreneurship Theory and Practice 24, 37-48.

Wiklund, J. \& Shepherd, D. (2003). Knowledge-based resources, entrepreneurial orientation, and the performance of small and medium-sized business. Strategic Management Journal, 24(13), 1307-1314.

Wong, S. S. (2004). Distal and local group learning: Performance trade-offs and tensions. Organization Science, 15, 645-656.

Zahra, S. A., \& Covin, J. G. (1995). Contextual Influences on the Corporate Entrepreneurship-Performance Relationship: A Longitudinal Analysis. Journal of Business Venturing 10, 43-58. 
Table 1. Entrepreneurial orientation, knowledge sharing and Performance for academic research groups. 2006-2010.

\begin{tabular}{|c|c|c|c|c|c|c|}
\hline & Total & $\mathbf{A} \& \mathbf{H}$ & Sciences & HS & $\mathbf{S} \& \mathbf{L S}$ & $\mathbf{E} \& \mathbf{A}$ \\
\hline \multicolumn{7}{|l|}{ ISI Articles } \\
\hline Mean & 20.40 & 9.05 & 24.5 & 40.08 & 17.30 & 14.28 \\
\hline Median & 12.00 & 9.50 & 23.00 & 26.00 & 12.00 & 4.50 \\
\hline SD & 24.51 & 5.74 & 16.15 & 42.46 & 15.90 & 19.26 \\
\hline Kruskal-Wallis Test & \multicolumn{6}{|l|}{$16.420^{* * * *}$} \\
\hline \multicolumn{7}{|l|}{ Knowledge Sharing } \\
\hline Mean & 0.06 & -0.18 & 0.29 & 0.29 & -0.13 & 0.22 \\
\hline Median & 0.09 & -0.22 & 0.28 & 0.36 & -0.20 & 0.22 \\
\hline SD & 0.62 & 0.61 & 0.43 & 0.48 & 0.73 & 0.62 \\
\hline Kruskal-Wallis Test & $9.824^{* *}$ & & & & & \\
\hline \multicolumn{7}{|l|}{ EO_Innovativeness } \\
\hline Mean & -0.01 & -0.07 & -0.15 & -0.12 & 0.03 & 0.26 \\
\hline Median & 0.02 & 0.00 & 0.12 & -0.15 & -0.03 & 0.22 \\
\hline SD & 0.68 & 0.56 & 0.87 & 0.57 & 0.89 & 0.34 \\
\hline Kruskal-Wallis Test & 3.753 & & & & & \\
\hline \multicolumn{7}{|l|}{ EO_Pro-activeness } \\
\hline Mean & 0.05 & -0.15 & 0.11 & 0.51 & -0.15 & 0.13 \\
\hline Median & 0.09 & -0.19 & 0.36 & 0.52 & -0.23 & 0.04 \\
\hline SD & 0.70 & 0.60 & 0.66 & 0.51 & 0.75 & 0.80 \\
\hline Kruskal-Wallis Test & $12.574^{* * *}$ & & & & & \\
\hline
\end{tabular}

\section{EO_Risk Propensity}

$\begin{array}{lcccccc}\text { Mean } & 0.06 & -0.06 & 0.31 & 0.17 & -0.14 & 0.20 \\ \text { Median } & 0.08 & -0.05 & 0.19 & 0.41 & -0.17 & 0.23 \\ \text { SD } & 0.68 & 0.70 & 0.75 & 0.62 & 0.67 & 0.60\end{array}$

Kruskal-Wallis Test $\quad 6.411$

A\&H: Art and Humanities; Sciences; HS: Health Sciences; S \& LS: Social and Law Sciences; E\&A: Engineering and Architecture 
Table 2. Entrepreneurial orientation, knowledge sharing and Performance

\begin{tabular}{lcccc}
\hline & mean & median & sd & t-test \\
\hline ISI Articles & & & & \\
High EO_innovativeness & 18.73 & 11.50 & 25.97 & \\
Low EO_innovativeness & 22.12 & 15.00 & 23.11 & 0.6426 \\
\hline High EO_pro-activeness & 27.39 & 15.50 & 30.93 & \\
Low EO_pro-activeness & 13.26 & 11.00 & 12.15 & $-2.7927 * * *$ \\
"wigh EO_risk taking & 22.68 & 14.00 & 23.62 & \\
Low EO_risk taking & 18.07 & 12.00 & 25.46 & -0.8763 \\
\hline Knowledge Sharing & & & & \\
\hline High EO_innovativeness & 0.2893 & 0.3196 & 0.4886 & \\
Low EO_innovativeness & -0.1762 & -0.2079 & 0.6682 & $-3.6873^{* * * *}$ \\
"High EO_pro-activeness & 0.1919 & 0.1595 & 0.5553 & \\
Low EO_pro-activeness & -0.0788 & -0.1096 & 0.6711 & $-2.0382^{* * * *}$ \\
High EO_risk taking & 0.2720 & 0.1845 & 0.5564 & \\
Low EO_risk taking & -0.1590 & -0.1096 & 0.6257 & $-3.3754^{* * * *}$ \\
\hline
\end{tabular}


Table 3. Descriptive statistics and correlation matrix

\begin{tabular}{|c|c|c|c|c|c|c|c|c|c|c|c|c|}
\hline & \multirow{2}{*}{ Mean } & \multirow{2}{*}{ Median } & \multirow{2}{*}{ S.D. } & \multicolumn{9}{|c|}{ Correlations } \\
\hline & & & & 1 & 2 & 3 & 4 & 5 & 6 & 7 & 8 & 9 \\
\hline 1. ISI Articles & 20.40 & 12.00 & 24.51 & 1 & & & & & & & & \\
\hline 2. Knowledge Sharing & 0.05 & 0.10 & 0.63 & 0.11 & 1 & & & & & & & \\
\hline 3. EO_Innovativeness & -0.01 & 0.02 & 0.68 & -0.04 & $0.40^{* * * *}$ & 1 & & & & & & \\
\hline 4. EO_Pro-activeness & 0.05 & 0.09 & 0.70 & $0.30^{* * *}$ & $0.26^{* *}$ & 0.05 & 1 & & & & & \\
\hline 5. EO_Risk Propensity & 0.06 & 0.08 & 0.68 & -0.04 & $0.53^{* * * *}$ & -0.06 & -0.02 & 1 & & & & \\
\hline 6. Size & 11.27 & 10.00 & 7.97 & $0.34^{* * *}$ & -0.13 & -0.03 & 0.14 & -0.06 & 1 & & & \\
\hline 7. Ph. D. Members & 0.69 & 0.66 & 0.20 & 0.11 & $-0.19^{*}$ & -0.05 & -0.17 & $-0.23^{* *}$ & -0.17 & 1 & & \\
\hline 8. Civil Servant Members & 0.54 & 0.51 & 0.18 & 0.03 & 0.10 & 0.11 & -0.02 & 0.05 & -0.08 & 0.21 & 1 & \\
\hline 19. External Researchers & 0.06 & 0.00 & 0.10 & 0.00 & -0.04 & -0.09 & 0.02 & -0.11 & 0.12 & 0.06 & $-0.36^{* * *}$ & 1 \\
\hline 10. Dissertations-adjusted & 0.84 & 0.00 & 2.82 & $0.44^{* * *}$ & -0.03 & -0.01 & 0.12 & -0.11 & $0.28^{* * * *}$ & $0.25^{* *}$ & 0.09 & 0.03 \\
\hline
\end{tabular}


Table 4. The mediating effect of knowledge sharing in entrepreneurial orientation and academic research group performance

Model: Simultaneous equation system (3SLS)

\begin{tabular}{|c|c|c|c|c|}
\hline \multirow{4}{*}{$\begin{array}{l}\text { Eq. 1. Dependent Variable } \\
\text { Knowledge Sharing }\end{array}$} & \multicolumn{2}{|c|}{ Model I } & \multicolumn{2}{|c|}{ Model II } \\
\hline & $\boldsymbol{B}$ & S. E. & $B$ & S. E. \\
\hline & \multicolumn{2}{|c|}{ ISI Articles } & \multicolumn{2}{|c|}{ Productivity } \\
\hline & $59.417^{* * * *}$ & (21.443) & $5.582^{* * * *}$ & $(1.910)$ \\
\hline EO_Innovativeness & $-20.269^{* * *}$ & $(9.313)$ & $-2.125^{* * *}$ & $(0.830)$ \\
\hline EO_Pro-activeness & -8.544 & (7.192) & -0.842 & $(0.641)$ \\
\hline EO_Risk Taking & $-26.758^{* * *}$ & (11.863) & $-2.539^{* * * *}$ & $(1.057)$ \\
\hline Civil Servant Members & -4.199 & (12.435) & -0.703 & $(0.988$ \\
\hline Ph.D. Members & $34.345^{* *}$ & (17.507) & $3.422^{* *}$ & $(1.548)$ \\
\hline External Researchers & 70.938 & $(68.288)$ & 3.099 & $(5.591)$ \\
\hline Squared External Researchers & $-426.384^{* *}$ & $(187.724)$ & $-26.996^{*}$ & (14.887) \\
\hline Size & $4.609^{* * * *}$ & (1.477) & $0.225^{*}$ & $(0.132)$ \\
\hline Squared Size & $-0.062^{* *}$ & $(0.025)$ & $-0.004^{* *}$ & $(0.002)$ \\
\hline Dissertations-adjusted & $2.55^{* * * *}$ & $(0.85)$ & $0.207^{\text {****}}$ & $(0.062)$ \\
\hline c $\quad+\quad \quad \quad \quad$ & $-43.867^{* *}$ & $(20.510)$ & -2.116 & (1.808) \\
\hline $\mathrm{Chi}^{2}$ Statistic & \multicolumn{2}{|r|}{$46.06^{* * *}$} & \multicolumn{2}{|c|}{$39.79^{* * * *}$} \\
\hline Eq. 2. Dependent Variable & \multicolumn{4}{|c|}{ Knowledge Sharing } \\
\hline EO_Innovativeness & $0.401^{\text {**** }}$ & $(0.064)$ & $0.404^{* * *}$ & $(0.064)$ \\
\hline EO_Pro-activeness & $0.197^{* * * *}$ & $(0.067)$ & $0.199^{* * * *}$ & $(0.067)$ \\
\hline EO_Risk Taking & $0.475^{\text {****}}$ & $(0.066)$ & $0.474^{* * * *}$ & (0.066) \\
\hline Ph.D. Members & -0.122 & $(0.245)$ & -0.118 & $(0.243)$ \\
\hline External Researchers & $0.793^{*}$ & $(0.479)$ & 0.760 & (0.477) \\
\hline Size & $-0.040^{* *}$ & $(0.018)$ & $-0.040^{* * *}$ & $(0.018)$ \\
\hline Squared Size & $5 e-4^{* *}$ & $(3 e-4)$ & $0.001^{*}$ & $(0.000)$ \\
\hline Sciences & $0.266^{* *}$ & $(0.119)$ & $0.294^{* *}$ & $(0.115)$ \\
\hline HS & $0.456^{* * *}$ & $(0.136)$ & $0.429^{* * * *}$ & $(0.134)$ \\
\hline S\&LS & 0.071 & $(0.084)$ & 0.059 & $(0.076)$ \\
\hline E\&A & 0.122 & $(0.112)$ & 0.092 & (0.103) \\
\hline c & 0.255 & $(0.265)$ & 0.261 & $(0.262)$ \\
\hline Chi2 Statistic & & $132.75^{* * * *}$ & & $32.76^{* * * *}$ \\
\hline
\end{tabular}

Notes:

(1) ${ }^{* * *}$ : Significant to $\mathrm{p}<0.01,{ }^{* *}: \mathrm{p}<0.05,{ }^{*}: \mathrm{p}<0.10$

(2) S.E.: Standard Error

(3) A\&H: Art and Humanities (is the omitted area); Sciences; HS: Health Sciences; S\&LS:

Social and Law Sciences; E\&A: Engineering and Architecture 
Table 5. Effects of EO dimensions on research team performance

\begin{tabular}{|c|c|c|c|c|c|c|}
\hline \multicolumn{2}{|c|}{$\begin{array}{l}\text { EO } \\
\text { innovativeness }\end{array}$} & \multirow{2}{*}{$\begin{array}{l}\begin{array}{l}\text { EO } \\
\text { proactiveness }\end{array} \\
0.0541\end{array}$} & \multirow{2}{*}{$\begin{array}{l}\begin{array}{l}\text { EO_risk } \\
\text { taking }\end{array} \\
0.0614\end{array}$} & \multirow{2}{*}{\begin{tabular}{|c|}
$\begin{array}{l}\text { Knowledge } \\
\text { Sharing }\end{array}$ \\
0.0565
\end{tabular}} & \multirow{2}{*}{$\begin{array}{l}\begin{array}{l}\text { Direct Effect } \\
\text { EO Dimensions }\end{array} \\
-0.1745\end{array}$} & \multirow{2}{*}{$\begin{array}{l}\text { Total } \\
\text { Effect }\end{array}$} \\
\hline For the mean & -0.0127 & & & & & \\
\hline $\begin{array}{l}\text { For the } \\
\text { median }\end{array}$ & 0.0163 & 0.0945 & 0.0846 & 0.0999 & -0.3290 & 0.2288 \\
\hline \multirow{2}{*}{\multicolumn{2}{|c|}{ Knowledge Sharing }} & Coef. & & & & \\
\hline & & 5.5821 & & & & \\
\hline \multicolumn{2}{|c|}{ EO innovativeness } & -2.1246 & & & & \\
\hline \multicolumn{2}{|c|}{ EO pro-activeness } & -0.8418 & & & & \\
\hline \multicolumn{2}{|l|}{ EO risk taking } & -2.5388 & & & & \\
\hline
\end{tabular}




\section{APPENDIX I}

Table A1.1. Confirmatory factor analysis for the entrepreneurial orientation scale

\begin{tabular}{|c|c|c|c|}
\hline Items & Com. & $\begin{array}{c}\text { Factor } \\
\text { load }\end{array}$ & $\begin{array}{l}\text { Cronbach's } \\
\text { alpha }\end{array}$ \\
\hline \multicolumn{3}{|l|}{ EO_Innovativeness } & \multirow{13}{*}{0.946} \\
\hline $\begin{array}{l}\text { My research group solve problems in a different way and } \\
\text { using different perspectives }\end{array}$ & $\begin{array}{c}0.86 \\
4\end{array}$ & 0.794 & \\
\hline $\begin{array}{l}\text { My research group propose new ways to approach the task } \\
\text { and projects. }\end{array}$ & $\begin{array}{c}0.85 \\
8\end{array}$ & 0.764 & \\
\hline My research group find new ways of doing things & $\begin{array}{c}0.86 \\
2\end{array}$ & 0.750 & \\
\hline My research group approach tasks in innovative ways & $\begin{array}{c}0.82 \\
0\end{array}$ & 0.731 & \\
\hline \multicolumn{3}{|l|}{ EO_Pro-activeness } & \\
\hline $\begin{array}{l}\text { My research group is very often the first to introduce new } \\
\text { topics or lines of research }\end{array}$ & $\begin{array}{c}0.78 \\
1\end{array}$ & 0.803 & \\
\hline $\begin{array}{l}\text { My research group keep ahead of changes instead of } \\
\text { responding to them }\end{array}$ & $\begin{array}{c}0.82 \\
6\end{array}$ & 0.803 & \\
\hline $\begin{array}{l}\text { My research group refer to other researchers in their field of } \\
\text { research }\end{array}$ & $\begin{array}{c}0.67 \\
9\end{array}$ & 0.773 & \\
\hline $\begin{array}{l}\text { My research group typically initiates actions to which other } \\
\text { researchers follow }\end{array}$ & $\begin{array}{c}0.69 \\
6\end{array}$ & 0.688 & \\
\hline \multicolumn{3}{|l|}{ EO_Risk taking } & \\
\hline $\begin{array}{l}\text { In the research group we do not mind working under } \\
\text { conditions of uncertainty }\end{array}$ & $\begin{array}{c}0.93 \\
2\end{array}$ & 0.906 & \\
\hline $\begin{array}{l}\text { My research group will take calculated risks despite the } \\
\text { possibility of failure }\end{array}$ & $\begin{array}{c}0.78 \\
4\end{array}$ & 0.772 & \\
\hline Total \% explained variance & \multicolumn{3}{|c|}{81.010} \\
\hline Kaiser-Meyer-Olkin & \multirow{2}{*}{\multicolumn{3}{|c|}{$\begin{array}{l}0.913 \\
2997.770^{* * * *}\end{array}$}} \\
\hline Barlett's test of sphericity: & & & \\
\hline \multicolumn{4}{|l|}{ Cronbach's Alpha } \\
\hline EO innovativeness & \multicolumn{3}{|l|}{0.9323} \\
\hline EO pro-activeness & \multicolumn{3}{|l|}{0.9569} \\
\hline EO risk taking & \multicolumn{3}{|l|}{0.9188} \\
\hline
\end{tabular}


Table A1.2. Confirmatory factor analysis for Sharing Knowledge

\begin{tabular}{|c|c|c|c|}
\hline Items & Com. & $\begin{array}{l}\text { Factor } \\
\text { Load }\end{array}$ & $\begin{array}{c}\text { Cronbach's } \\
\text { alpha }\end{array}$ \\
\hline $\begin{array}{l}\text { My research group members always give their studies } \\
\text { and research knowledge to others }\end{array}$ & 0.863 & 0.929 & \multirow{10}{*}{0.971} \\
\hline $\begin{array}{l}\text { My research group members share their research results } \\
\text { (new articles, projects, etc.) with each other. }\end{array}$ & 0.827 & 0.910 & \\
\hline $\begin{array}{l}\text { My research group members share their research } \\
\text { experience with the rest }\end{array}$ & 0.809 & 0.899 & \\
\hline $\begin{array}{l}\text { In stressful situations, group members always help each } \\
\text { other }\end{array}$ & 0.805 & 0.897 & \\
\hline $\begin{array}{l}\text { Often, my research group members make suggestions to } \\
\text { others on the best investigation methods }\end{array}$ & 0.779 & 0.883 & \\
\hline $\begin{array}{l}\text { Members of my research group understand the problems } \\
\text { and research needs of the rest }\end{array}$ & 0.767 & 0.876 & \\
\hline $\begin{array}{l}\text { Members of my research group usually tell each other if } \\
\text { there is a research activity that can facilitate the work of } \\
\text { others }\end{array}$ & 0.746 & 0.864 & \\
\hline $\begin{array}{l}\text { In stressful situations, group members always ask each } \\
\text { other for help }\end{array}$ & 0.734 & 0.857 & \\
\hline $\begin{array}{l}\text { Members of my research group always recognize the } \\
\text { research potential of the rest }\end{array}$ & 0.706 & 0.840 & \\
\hline $\begin{array}{l}\text { Members of my research group share their knowledge } \\
\text { with the rest if asked }\end{array}$ & 0.684 & 0.827 & \\
\hline Total \% explained variance & \multicolumn{3}{|c|}{77.217} \\
\hline Kaiser-Meyer-Olkin & \multicolumn{3}{|c|}{0.935} \\
\hline Barlett's test of sphericity: & \multicolumn{3}{|c|}{$3975.230^{* * * *}$} \\
\hline
\end{tabular}


APPENDIX II

Table A2.1. Definition of variables

\begin{tabular}{|c|c|}
\hline Variable & Description \\
\hline \multicolumn{2}{|r|}{ Dependent Variables } \\
\hline $\begin{array}{l}\text { Performance } \\
\text { (ISI Articles) }\end{array}$ & $\begin{array}{l}\text { The total number of articles published by each group during the period 2006- } \\
2010 \text { in journals belonging to Thomson Reuters ISI Web of Science database. }\end{array}$ \\
\hline $\begin{array}{l}\text { Performance } \\
\text { (Productivity) }\end{array}$ & $\begin{array}{l}\text { The number of ISI articles of each group divided by the average number of group } \\
\text { members for the period. }\end{array}$ \\
\hline Knowledge Sharing & $\begin{array}{l}\text { This variable was measured with a 10-item scale, which was adapted from Hsu } \\
\text { et al. (2007), Chow \& Chan (2008), and Liu et al. (2011). }\end{array}$ \\
\hline \multicolumn{2}{|r|}{ Explanatory Variables } \\
\hline $\begin{array}{l}\text { Entrepreneurial } \\
\text { orientation }\end{array}$ & $\begin{array}{l}\text { This variable was measured with a } 10 \text {-item scale developed to reflect the } \\
\text { innovativeness, pro-activeness and risk propensity of the research group (Covin } \\
\text { and Slevin, 1989; Stull and Singh, 2005). }\end{array}$ \\
\hline \multicolumn{2}{|r|}{ Control Variables } \\
\hline Group Size & The average number of research members per group for the period 2006-2010. \\
\hline $\begin{array}{l}\text { Dissertations- } \\
\text { adjusted }\end{array}$ & $\begin{array}{l}\text { The number of dissertations defended during the period } 2006-2010 \text { for each } \\
\text { research group, adjusted by the mean for the knowledge area. }\end{array}$ \\
\hline Ph. D. Members & The percentage of members holding a Ph.D. in each group. \\
\hline $\begin{array}{l}\text { Civil Servant } \\
\text { Members }\end{array}$ & The percentage of civil servants in each research group. \\
\hline External Researchers & The percentage of researchers from other universities in each research group. \\
\hline Knowledge area & $\begin{array}{l}\text { Five dummy variables, which adopt the value } 1 \text { if the group belongs to a specific } \\
\text { area: arts and humanities, social and law sciences, sciences, health sciences and } \\
\text { engineering and architecture. }\end{array}$ \\
\hline
\end{tabular}

